\title{
MOLYBDENITE IN THE FISKENÆSSET ANORTHOSITE COMPLEX, SOUTHERN WEST GREENLAND
}

\author{
John S. Myers
}

During the past few seasons mapping of early Precambrian rocks in the Fiskenæsset region (Kalsbeek, this report), the author has noted the widespread occurrence of molybdenite in the Majorqap qâva outcrop of the Fiskenæsset anorthosite complex. This outcrop lies $35 \mathrm{~km}$ north-east of Fiskenæesset town, north of Fiskenæsfjorden (Myers, 1973). Elsewhere in the Archaean rocks of Greenland, substantial amounts. of molybdenite have only been found in supracrustal amphibolites in the Godthåb region by Kryolitselskabet Øresund $A / S$ at Ivisârtoq (Nielsen, 1973) and V. R. McGregor at Narssaq.

The Fiskenæsset anorthosite complex occurs as layers generally $300 \mathrm{~m}$ or less thick and as small inclusions, in both amphibolites and quartzo-feldspathic gneisses throughout the Fiskenæsset region, an area of over $3000 \mathrm{~km}^{2}$ (see plate 1, Rapp. Gronlands geol. Unders. 51, 1973). The complex is a metamorphosed layered igneous intrusion containing large quantities of chromite (Ghisler \& Windley, 1967) and smaller amounts of magnetite.

The Majorqap qâva outcrop consists of four major units which are, in primary upward succession: lower leucogabbro $(50 \mathrm{~m})$, gabbro $(40 \mathrm{~m})$, upper leucogabbro $(60 \mathrm{~m})$ and anorthosite $(200 \mathrm{~m})$. In the field, molybdenite was seen in all four units and in stratigraphic horizons ranging from near the bottom to the top of the succession. It was most commonly seen in anorthosite and leucogabbro rocks composed of plagioclase (An 80-98) and hornblende, as platy crystals 2$3 \mathrm{~mm}$ across, but was seen in one place as crystals $2 \mathrm{~cm}$ across. In some places molybdenite is associated with pyrite and other metal sulphides, and in some places with chromite.

During the collection of a suite of large samples in a single traverse across all the main layers from the bottom of the complex to the lower part of the upper leucogabbro unit, molybdenite was seen in the field in four out of nineteen samples. Elsewhere where suites of samples were systematically collected, molybdenite was seen in about one out of every twenty samples, but no search was made especially for molybdenite. In most places it was seen in relatively little deformed parts of the anorthosite complex and for this reason, together with its apparent abundance, it appears to be a primary associate of the anorthosite complex.

Molybdenite was also seen in a vein of garnet anorthosite which cross-cuts a tectonic fabric of the main anorthosite outcrop, and in a rusty weathering quartz vein rich in sulphide minerals which cross-cuts the lower leucogabbro unit. The anorthosite vein is considered to have been derived by partial melting of the 
main anorthosite unit during deformation. The quartz vein appears to be associated with granite and aplite veins from the main, now gneissose, granite which surrounds the complex. Therefore in both these cases the molybdenite may have been derived from the older layered anorthosite complex.

Smaller amounts of molybdenite also occur in garnet-biotite quartzite in a small patch of metasediments engulfed by the same gneissose granite which surrounds the anorthosite complex, $500 \mathrm{~m}$ west of the Majorqap qâva outcrop. Molybdenite also occurs in gneisses elsewhere in the Fiskenæsset region (Ghisler \& Kalsbeek, personal communication), and in an amphibolite dyke which cuts across deformed anorthosite on the southern shore of Ameralik, $100 \mathrm{~km}$ to the north.

Many of the supracrustal amphibolites of the Fiskenæsset region are considered to be derived from volcanic rocks closely associated with, and the precursors of, the intrusion of the anorthosite complex (Windley et al., 1973). If this is so, and the molybdenite in both the supracrustal amphibolites and the anorthosite complex is of primary association with these rock units, then the early magmas which were their parents were rich in molybdenum. The molybdenite in the amphibolite dyke, anorthosite vein and quartz vein was perhaps derived subsequently from the anorthosite complex during deformation and metamorphism.

The Fiskenæsset region therefore appears to be part of a molybdenum-rich province in which molybdenum was primarily associated with anorthosite complexes and metavolcanics. It is not known whether workable concentrations of molybdenite occur, but attention is drawn to this new, apparently abundant, occurrence in case the additional presence of molybdenite together with the known substantial deposits of chromite and lesser amount of magnetite, should bring these readily accessible anorthosite outcrops closer to economic viability.

\section{References}

Ghisler, M. \& Windley, B. F. 1967: The chromite deposits of the Fiskenæsset region, West Greenland. Rapp. Grønlands geol. Unders. 12, 39 pp.

Myers, J. S. 1973: Igneous structures and textures in the Majorqap qâva outcrop of the Fiskenæsset anorthosite complex. Rapp. Grønlands geol. Unders. 51, 47-53.

Nielsen, B. L. 1973: A survey of the economic geology of Greenland (exclusive fossil fuels). Rapp. Grønlands geol. Unders. 56, 45 pp.

Windley, B. F., Herd, R. K. \& Bowden, A. A. 1973: The Fiskenæsset complex, West Greenland. Part 1. A preliminary study of the stratigraphy, petrology, and whole rock chemistry from Qeqertarssuatsiaq. Bull. Grønlands geol. Unders. 106 (also Meddr Grønland 196, 2) $80 \mathrm{pp}$. 